PNL-7778

UC-812

\title{
Cost Estimates of Operating Onsite Spent Fuel Pools After Final Reactor Shutdown
}

S. R. Rod

August 1991

Prepared for the U.S. Department of Energy under Contract DE-AC06-76RLO 1830

Pacific Northwest Laboratory

Operated for the U.S. Department of Energy by Battelle Memorial Institute 


\title{
DISCLAIMER
}

This report was prepared as an account of work sponsored by an agency of the United States Government. Neither the United States Government nor any agency thereof, nor Battelle Mernorial institute, nor any of their employees, makes any warranty, expressed or implied, or assumes any legal liability or responsibility for the accuracy, completeness, or usefulness of any information, apparatus, product, or process disclosed, or represents that its use would not infringe privately owned rights. Reference herein to any specific commercial product, process, or service by Irade name, trademark, manufaclurer, or otherwise does not necessarily constitute or imply its endorsement, recommendation, or favoring by the United States Government or any agency thereof, or Battelle Memorial Institute. The views and opinions of authors expressed herein do not necessarily state or reflect those of the United States Government or any agency thereof.

\author{
PACIFIC NORTHWEST LABORATORY \\ operated by \\ BATTELLE MEMORIAL INSTITUTE \\ for the \\ UNITED STATES DEPARTMENT OF ENERGY \\ under Contract DE-ACO6-76RLO 1830
}

\author{
Printed in the United States of America
}

Available to DOE and DOE contracturs from the

Office of Scientific and Technical Information, P.O. Box 62, Oak Ridge, TN 37831; prices available from (615) 576-4401. FTS 626-8401.

\footnotetext{
Availatle to the puhlic from the National Technical Information Service, U.S. Department of Commerce, 52 b5 Port Royal Rd., Springrield, VA 22161.
} 
PNL-7778

UC-812

COST ESTIMATES OF OPERATING ONSITE SPENT FUEL POOLS AFTER FINAL

REACTOR SHUTDOWN

S. R. Rod

August 1991

Prepared for

the U.S. Department of Energy

under Contract DE-ACO6-76RLO 1830

Pacific Northwest Laboratory

Richland, Washington 99352 



\section{EXECUTIVE SUMMARY}

This report presents estimates of the annual costs of operating spent fuel pools at nuclear power stations after the final shutdown of one or more onsite reactors. Its purpose is to provide basic spent fuel storage cost information for use in evaluating DOE's reference nuclear waste management system, as well as alternate systems. The basic model of an independent spent fuel storage installation (ISFSI) used in this study was based on General Electric Corporation's Morris Operation and was modified to reflect mean storage capabilities at an unspecified, or "generic," U.S. reactor site. Cost data for the model came from several sources, including both operating and shutdown nuclear power stations and existing ISFSIs. Duke Power Company has estimated ISFSI costs based on existing spent fuel storage costs at its nuclear power stations. Similarly, nuclear material handling facilities such as the Morris Operation, the West Valley Demonstration Project, and the retired Humbolt Bay nuclear power station have compiled spent fuel storage cost data based on years of operating experience.

Consideration was given to the following factors that would cause operating costs to vary among pools: 1) the number of spent fuel pools at a given reactor site, 2) the number of operating and shutdown reactors onsite, 3) geographic location, and 4) pool storage capacity. Tables are included that show the best estimates of the costs (in 1989 dollars) of operating spent fuel pools at reactor sites with one, two, and three reactors shut down. Entries in the tables include only the cost of operating inactive pools, which are no longer receiving spent fuel from reactors (i.e., operating in a "storage-only" mode). Costs associated with pools actively receiving spent fuel from onsite operating reactors were assumed to be included in routine plant operation costs. Operating one inactive "storage-only" pool was estimated to cost about $\$ 3,670,000$ annually; two inactive pools were estimated to cost about $\$ 4,130,000$ annually; and three inactive pools were estimated to cost about $\$ 4,800,000$ annually. Costs are esentially independent of reactor type.

Monte Carlo simulations were performed to estimate the variations in the inactive pool operating costs (listed in Table 2.1) due to the geographic and pool capacity factors. The statistics for individual cost variables were derived from the references cited for the original cost estimates. The range of cost variation for a site with a single spent fuel pool and all reactors shut down is summarized in Table 2.2. 



\section{CONTENTS}



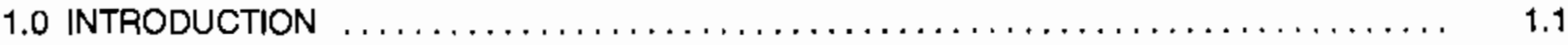

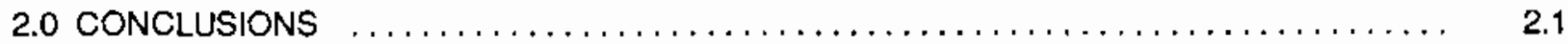

2.1 NOMINAL SPENT FUEL POOL OPERATION COSTS $\ldots \ldots \ldots \ldots \ldots \ldots \ldots \ldots \ldots \ldots .2 .1$

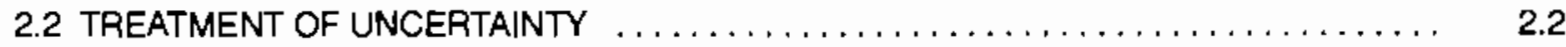

2.3 ANNUAL COST PER UNIT STORAGE CAPACITY $\ldots \ldots \ldots \ldots \ldots \ldots \ldots \ldots \ldots \ldots \ldots \ldots \ldots$

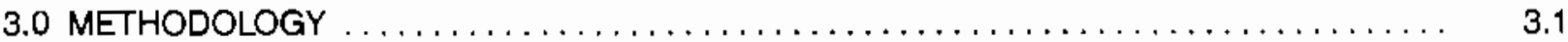

3.1 DESCRIPTION OF THE MODEL ISFSI $\ldots \ldots \ldots \ldots \ldots \ldots \ldots \ldots \ldots \ldots \ldots \ldots \ldots \ldots \ldots \ldots \ldots$



3.3 COST ADJUSTMENTS FOR GEOGRAPHIC VARIATION $\ldots \ldots \ldots \ldots \ldots \ldots \ldots \ldots \ldots$

3.4 COST ADJUSTMENTS FOR POOL CAPACITY VARIATION $\ldots \ldots \ldots \ldots \ldots \ldots \ldots \ldots \ldots$.

3.5 COSTS FOR SECOND AND THIRD POOLS ON THE SITE $\ldots \ldots \ldots \ldots \ldots \ldots \ldots \ldots$

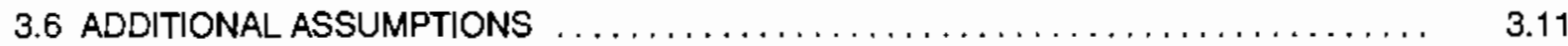

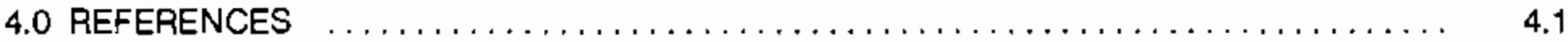

APPENDIX A - BACKGROUND SURVEY CONTACTS $\ldots \ldots \ldots \ldots \ldots \ldots \ldots \ldots \ldots \ldots$ A.1

APPENDIX B - MORRIS OPERATION ORGANIZATION CHART $\ldots \ldots \ldots \ldots \ldots \ldots \ldots \ldots \ldots \ldots \ldots \ldots \ldots$ 


\section{FIGURES}

2.1 Costs of Operating Spent Fuel Pools: Variation Due to Geographic Factors $\ldots \ldots \ldots \ldots \quad 2.3$

2.2 Costs of Operating Spent Fuel Pools: Variation Due to Differing Pool Capacities $\ldots \ldots \ldots \quad 2.3$

2.3 Costs of Operating Spent Fuel Pools: Overall Variability $\ldots \ldots \ldots \ldots \ldots \ldots \ldots \ldots \ldots \ldots$

2.4 Annual Cost-per-kgU of Operating Spent Fuel Pools: Distribution Among



3.1 At-Reactor Spent Fuel Storage Capacities $\ldots \ldots \ldots \ldots \ldots \ldots \ldots \ldots \ldots \ldots \ldots \ldots \ldots \ldots \ldots \ldots \ldots$

3.2 Spent Fuel Pool Operation Cost Estimates $\ldots \ldots \ldots \ldots \ldots \ldots \ldots \ldots \ldots \ldots \ldots \ldots \ldots \ldots$

\section{TABLES}

2.1 Estimated Annual Operation Costs of Onsite Spent Fuel Storage at Shutdown Reactors ...

2.2 Spent Fuel Pool Operation Cost Variations: Single-Pool Site with All Reactors

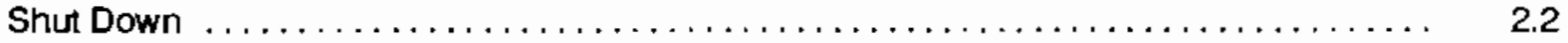

3.1 Spent Fuel Pool Annual Costs for Long-Term Operation at a

750-MTU-Capacity ISFSI

3.2 Geographically Adjusted Annual Cost for a Generic 750-MTU-Capacity

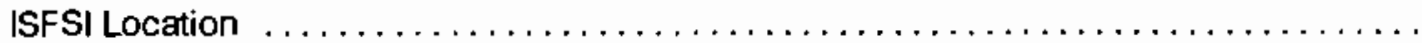

3.3 Final Adjusted Annual Operating Cost of an Average Capacity

ISFSI at a Generic U.S. Location

3.4 Annual Costs for Long-Term Operation of an Additional Spent Fuel Pool at an ISFSI . . . . $\quad 3.9$

3.5 Annual Costs for Long-Term Operation of a Second Additional Spent Fuel Pool

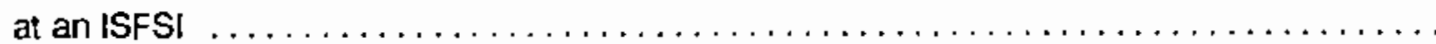




\subsection{INTRODUCTION}

The U.S. Department of Energy (DOE) Office of Civilian Radioactive Waste Management (OCRWM) is responsible for developing a system for the management of high-level radioactive waste and spent nuclear fuel in accordance with the Nuclear Waste Policy Act of 1982 (NWPA) and the Nuclear Waste Policy Amendments Act of 1987 (NWPAA). Pacific Northwest Laboratory (PNL) ${ }^{(a)}$ is assisting DOE in conducting the system engineering and system integration activities required to develop, design, and deploy the federal waste management system. In the context of system engineering studies, there is a need to estimate 1) the costs of onsite spent fuel storage at shutdown reactors, and 2) the sensitivities of these cost estimates to spent fuel allocation and receipt timing.

The need for pool operating cost estimates is generic across several current and proposed studies, including the Reference System Performance Evaluation (RSPE), which is intended to provide the reference point from which comparisons of alternative system configurations and their performances can be made.

To evaluate the cost-effectiveness of the reference system and alternative configurations, information is needed on the cost of various aspects of spent nuclear fuel management. Specifically, data on the cost of storing spent fuel elements on the sites at which they were produced and after final reactor shutdown are required input for the system cost evaluation model, "System Engineering Cost Analysis Capability" (Humphreys et al. 1990).

This report presents estimates of the annual costs (in 1989 dollars) of operating spent fuel pools at nuclear power stations atter the final shutdown of one or more onsite reactors. It is based on a survey of existing literature and consultations with key personnel at operating spent fuel storage facilities. The report includes assumptions, references, and supporting information.

For compatibility with the data table used by the System Engineering Cost Analysis Model (SECAM) (Humphreys et al. 1990), the cost values used in this report have been modeled after the PNL 'MRS Systems Study Task G Report" (Wood et al. 1989, p. B.6). Values for estimating annual operating costs of onsite spent fuel storage at shutdown reactors can be used as input to SECAM as long as they are carefully chosen to match the intended case(s) of the SECAM analysis.

information on spent fuel pools and wet-storage independent spent fuel storage installations (ISFSIs) was reviewed to identify the necessary cost categories for operating such a facility long-term. The broad cost categories identified include 1) personnel costs, 2) non-personnel costs (e.g., supplies and equipment), 3) plant services, 4) utilities (electric power only), and 5) administrative costs. Cost estimates were drawn from several data sources, both published and unpublished reports and interviews with cognizant experts. References are listed in the reference section at the end of this report; for information on interviews, see Appendix A.

(a) Pacific Northwest Laboratory is operated for the U.S. Department of Energy by Battelle Memorial Institute under Contract DE-AC06-76RLO 1830. 
Annual operating costs were estimated for the model (i.e., typical) facility. General Electric's (GE) Morris Operation, an ISFSI near Morris, Illinois, was used as a typical wet-storage facility (GE 1990). Its licensed capacity is close to the mean capacity of all spent fuel pools at commercial reactors (DOE 1989). In recent years, it has been operating virtually in a storage-only (e.g., ISFSI) mode. The facility's operation and maintenance programs appear to be typical of those that would be encountered at future wet-storage ISFSIs. The most significant alteration made to create the model ISFSI from the Morris Operation was the staffing level. Personnel requirements for the model ISFSI were increased over those of the Morris Operation to better reflect the likely staffing levels needed for utilities to comply with regulations governing ISFSIs starting operation in the future (based on discussions with cognizant personnel at commercial nuclear power plants).

The results of the study are presented in Section 2.0, and the cost estimation methodology is described in detail in Section 3.0. 


\subsection{CONCLUSIONS}

This section summarizes the findings of the study, including 1) best estimates of the annual costs for utilities to operate spent fuel pools as independent spent fuel storage installations (ISFSIS) at reactor sites with one, two, and three reactors shut down; 2) the uncertainty associated with these cost estimates due to geographic and pool capacity factors; and 3) the variation of annual cost-per-kgU (storage capacity in kilograms of uranium) among U.S. commercial reactor sites.

\subsection{NOMINAL SPENT FUEL POOL OPERATION COSTS}

Table 2.1 shows the best estimates of the annual costs of operating spent fuet pools as ISFSIs at reactor sites with one, two, and three reactors shut down. For compatibility with the data table used by the System Engineering Cost Analysis Model (SECAM), the information in the table has been adapted from the format of Table B.1 of the PNL report, 'MRS Systems Study Task G Report' (Wood et al. 1989, p. B.6). However, it was found in this current study that spent fuel storage costs depended on the number of spent fuel pools on the site as well as on the number of onsite reactors. Consequently, there

Table 2.1. Estimated Annual Operation Costs of Onsite Spent Fuel Storage at Shutdown Reactors ${ }^{(a)}$

\section{Situation at Reactor Site}

\begin{tabular}{|c|c|}
\hline Reactor Status & Pool Status \\
\hline 1 reactor shut down & $\begin{array}{l}1 \text { pool onsite: } \\
2 \text { pools onsite: } \\
3 \text { pools onsite: }\end{array}$ \\
\hline 2 reactors shut down & $\begin{array}{l}1 \text { pool onsite: } \\
2 \text { pools onsite: } \\
3 \text { pools onsite: } \\
\text { - } 1 \text { pool shut: } \\
\text { - } 2 \text { pools shut: }\end{array}$ \\
\hline 3 reactors shut down & $\begin{array}{l}1 \text { pool onsite: } \\
2 \text { pools onsite: } \\
3 \text { pools onsite: }\end{array}$ \\
\hline
\end{tabular}

Number of Reactors Onsite

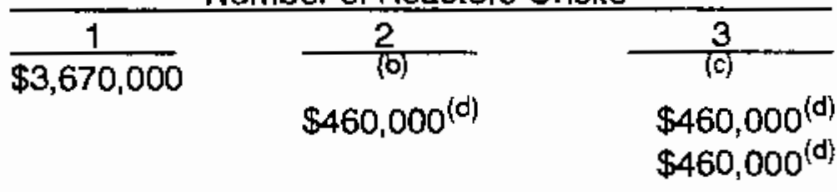

$\$ 3,670,000$

(c)

$\$ 4,130,000$ $\$ 460,000^{(d)}$

$\$ 460,000^{(d)}$ $\$ 1,130,000^{(d)}$

(c)

$\$ 4,130,000$

$\$ 4,800,000$

(a) Annual operating costs are in 1989 doliars. Only costs associated with "steedy-state," long-term spent fuel storage are included. Costs associated with receiving and shipping spent fuel elements are excluded (e.g., additional manpower, equipment, etc., for either receiving/unloading or loading and shipping transport casks). Other costs not included are:

- Facility decommissioning costs, including the cost of final disposition of liquid and solid radioactive wasles currently accumulated on the site for eventual disposal at decommissioning.

- Local, county, and state fees and taxes; notably, property taxes.

- For additional pools: extra insurance, licensing, inspection, and regulatory costs.

(b) In this case, the spent fuel pool operation costs would continue to be included in operating plant costs.

(c) This configuration does not exist at U.S. reactor sites.

(d) This assumes that utility chooses to shut down (i.e., cease to receive spent fuel) the pool(s) associated with the shutdown reactor(s), while one or more reactors continue to operate at the site. In this case, the operation costs of the pools remaining active would continue to be included in operating plant cosis. 
are more cost entries in Table 2.1 than there are in the equivalent table in the Task $G$ report. Nonetheless, values from Table 2.1 can be used as input to SECAM as long as table values are carefully chosen to match the intended case(s) of the SECAM analysis.

Entries in the table reflect the total cost of operating all inactive pools (i.e., pools not receiving spent fuel from reactors). in general, the cost allocation that is the basis for Table 2.1 was conducted with security costs assigned to an operating reactor if possible. A 3-reactor/3-pool site with two reactors shut down would incur a cost of $\$ 460,000$ per year for the first inactive pool and $\$ 670,000$ per year for the second inactive pool, totaling $\$ 1,130,000$ per year. Both a 2-reactor/2-pool site and a 3-reactor/2-pool site with all reactors shut down would cost $\$ 3,670,000+\$ 460,000$ or $\$ 4,130,000$ per year. A 3reactor/3-pool site with all reactors shut down would cost $\$ 3,670,000+\$ 460,000+\$ 670,000$ or $\$ 4,800,000$ per year.

\subsection{TREATMENT OF UNCERTAINTY}

To estimate the uncertainty associated with the cost estimates listed in Table 2.1, a Monte Carlo simulation of the distribution of costs due to the geographic and pool capacity factors is described in Section 3.0, "Methodology." The statistics for individual cost variables were derived from Wood et al. (1989) and Humphreys et al. (t990). The results are summarized in Table 2.2 and in Figures 2.1, 2.2. and 2.3.

Uncertainty in this analysis ascribed to geographic and capacity factors could be reduced by specifying the relevant values for individual sites in a more detailed assessment (i.e., a site-specific version of Table 2.1). Site-specific data are available to help specify costs for a given location and pool capacity. At this time, however, SECAM cannot utilize site-specific cost data.

\subsection{ANNUAL COST PER UNIT STORAGE CAPACITY}

As can be seen in Table 2.2 and Figure 2.2, pool capacity affects the annual operating cost. While total operating costs tend to increase only slightly as pool storage capacity increases (a twenty-fold

Table 2.2. Spent Fuel Pool Operation Cost Variations: ${ }^{(a)}$ Single-Pool Site with All Reactors Shut Down

\begin{tabular}{|c|c|c|c|c|}
\hline $\begin{array}{l}\text { Variations Due to } \\
\text { Geographic Factors } \\
\text { (see Figure 2.1) }\end{array}$ & $\frac{\text { Expected Value }}{\$ 3,900,000}$ & $\frac{\text { Minimum Result }}{\$ 2,870,000}$ & $\frac{\text { Maximum Result }}{\$ 5,180,000}$ & $\frac{\text { Standard Deviation }}{\$ 330,000}$ \\
\hline $\begin{array}{r}\text { Capacity Factors } \\
\text { (see Figure 2.2) }\end{array}$ & $\$ 3,670,000$ & $\$ 2,850,000$ & $\$ 5,260,000$ & $\$ 440,000$ \\
\hline $\begin{array}{l}\text { Combined Factors } \\
\text { (s)e Figure } 2.3 \text { ) }\end{array}$ & $\$ 3,670,000$ & $\$ 2,270,000$ & $\$ 6,000,000$ & $\$ 550,000$ \\
\hline
\end{tabular}

(a) Based on 2,000-sample Monte Carlo simulation.

(b) Combined geographic and capacity factors. 


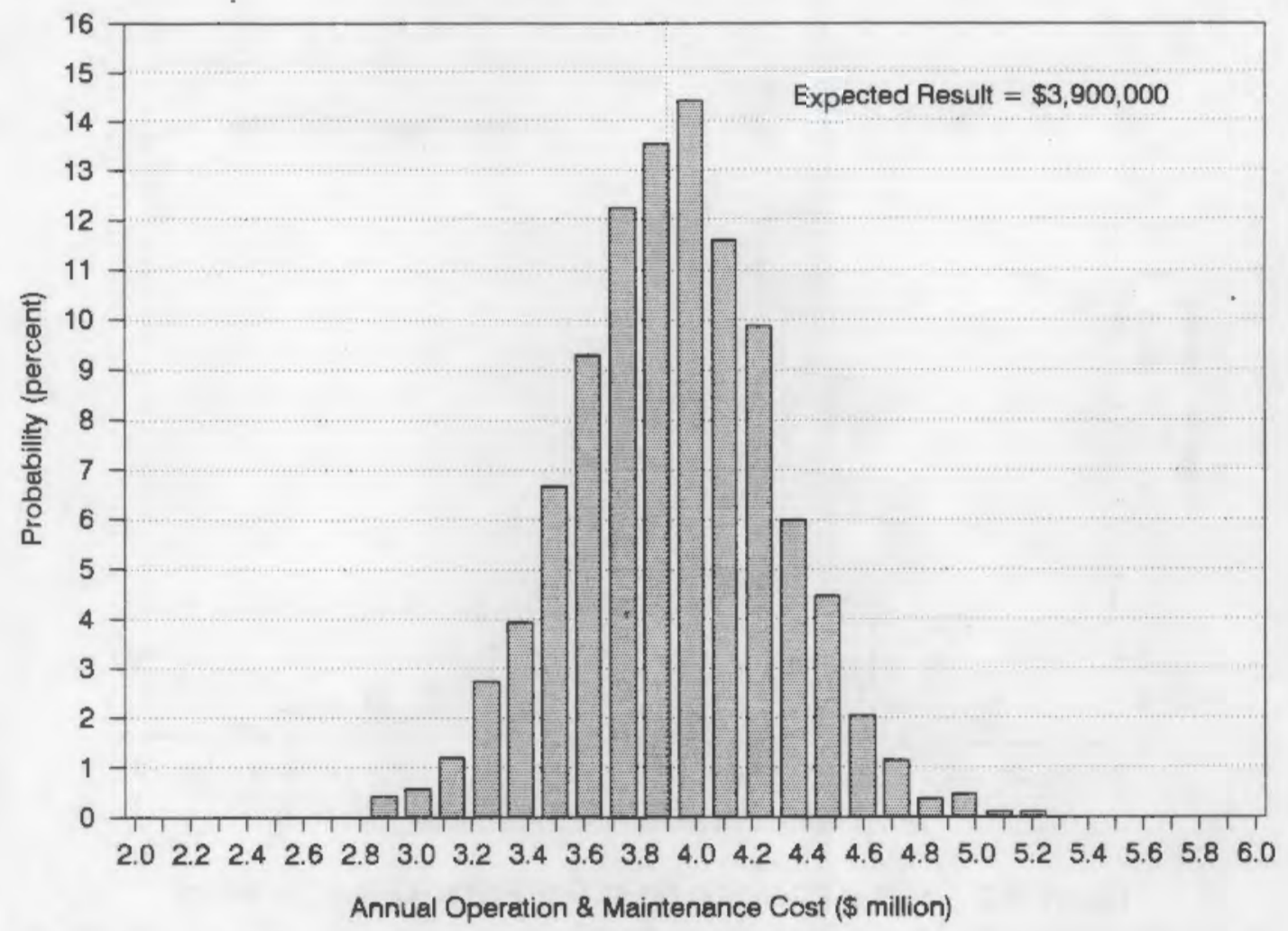

Figure 2.1. Costs of Operating Spent Fuel Pools: Variation Due to Geographic Factors

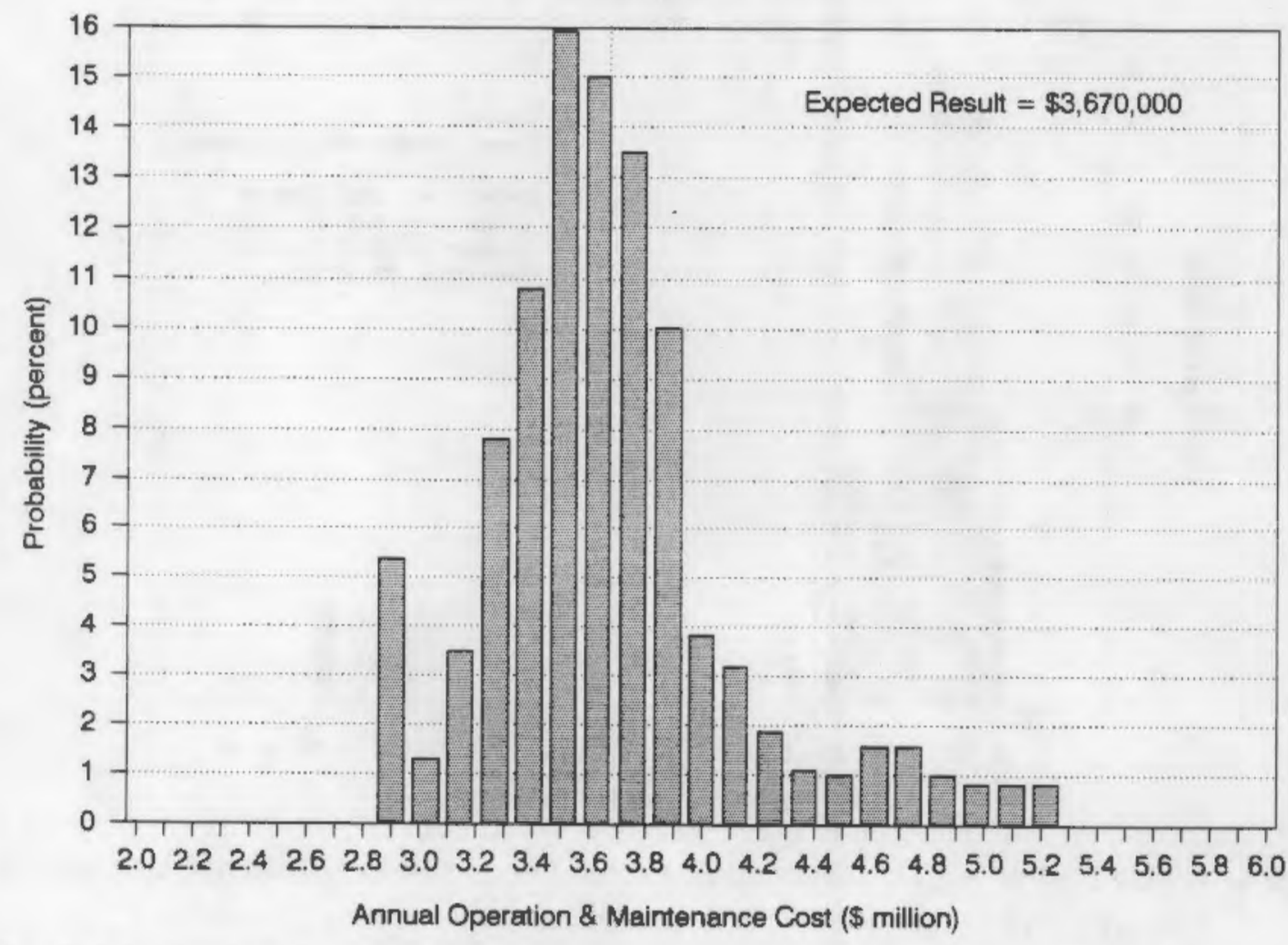

Figure 2.2. Costs of Operating Spent Fuel Pools: Variation Due to Differing Pool Capacities (Generally, operating costs increase as pool capacity increases.) 


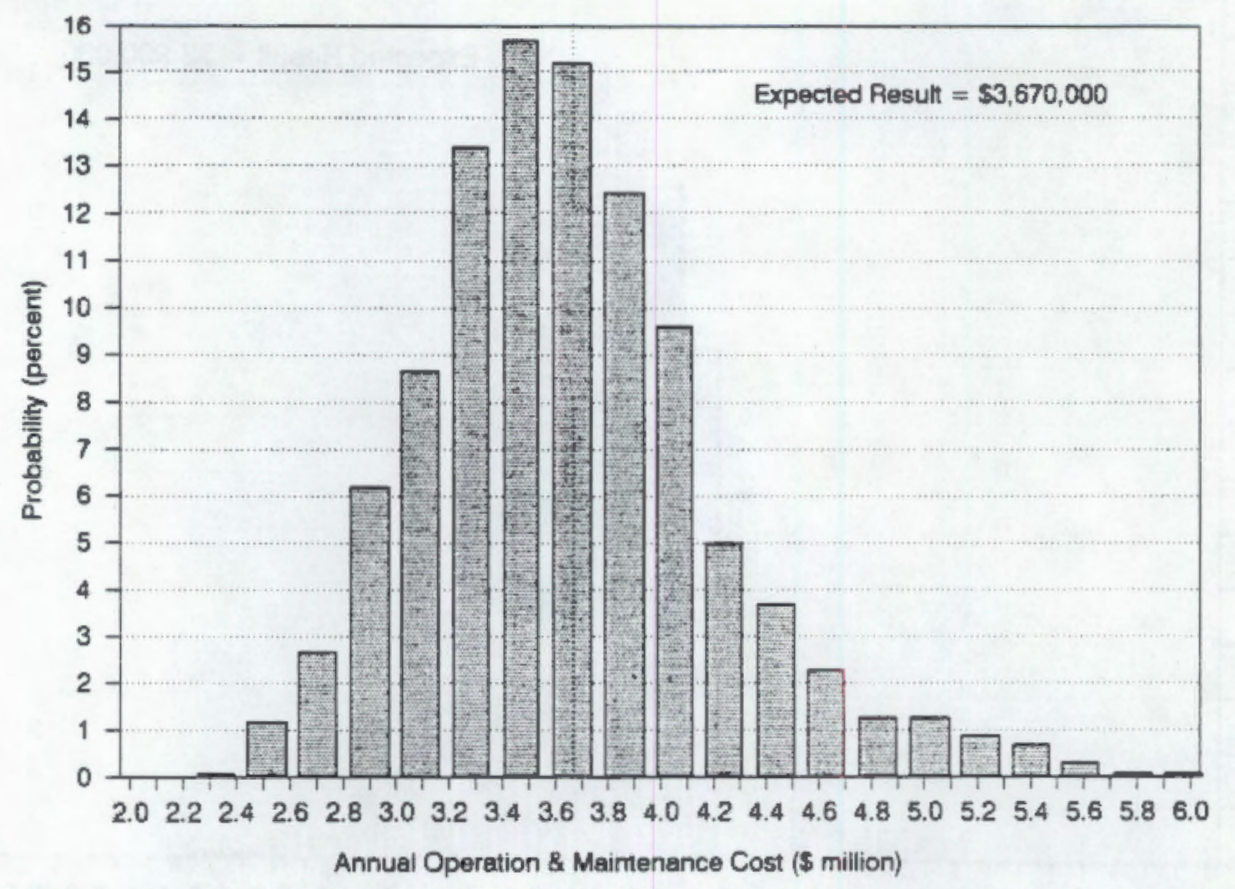

Figure 2.3. Costs of Operating Spent Fuel Poois: Overall Variability

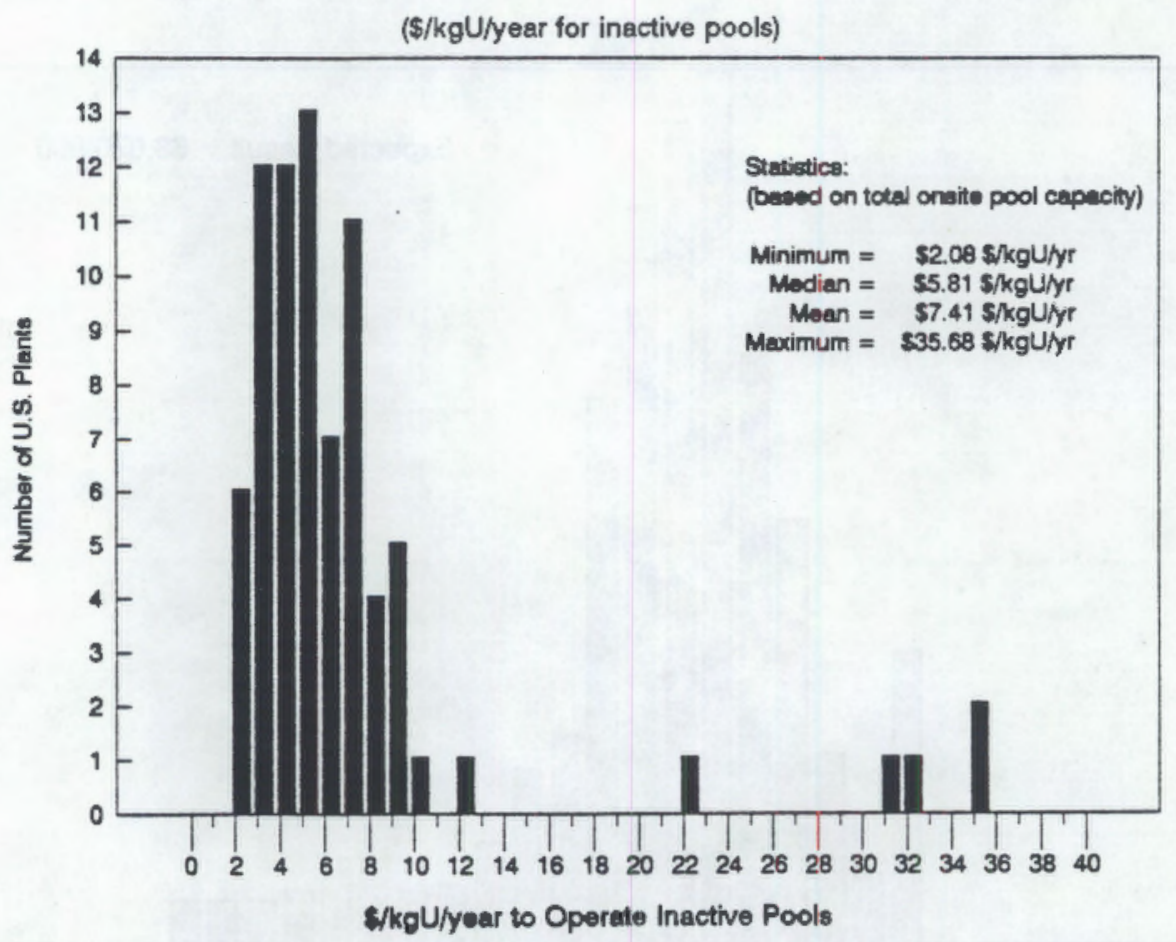

Figure 2.4. Annual Cost-per-kgU of Operating Spent Fuel Pools: Distribution Among U.S. Reactor Sites (Generally, operating costs-per-kgU decrease as pool capacity increases.) 
increase in pool capacity yields only a two-fold increase in annual operating cost), operating cost-per-kgU decreases dramatically as the pool capacity increases. Figure 2.4 shows the estimated annual operating costs-per-kgU of total onsite storage capacity for U.S. commercial reactor sites. The expensive outliers are all older facilities with relatively small pools. Nonetheless, ISFSI operating costsper-kgU per year still will probably vary by about a factor of three among the main population of U.S. nuclear power plants. 


\subsection{METHODOLOGY}

This section describes the methods used to estimate the annual costs of operating one or more spent fuel pools at shutdown reactor sites. First, the unit cost components for operating a spent fuel pool or pools as an independent spent fuel storage installation (ISFSI) were categorized and estimated from collected reference material. These unit costs were then applied to a model of a typical future utility-operated ISFSI, including staffing levels, material consumption, utility requirements, etc. The initial estimates of annual operating costs were for a single spent fuel pool. Similar cost estimates were made for sites with one or two additional spent fuel pools.

\subsection{DESCRIPTION OF THE MODEL ISFSI}

General Electric's Morris Operation, an ISFSI near Morris, Illinois (adjacent to the Dresden Nuclear Power Station), was used as a typical wet-storage facility. Its licensed capacity of 750 metric tons of uranium (MTU) is only slightly greater than the mean capacity, 595 MTU, of all spent fuel pools at commercial reactors (DOE 1989; GE 1990). It has been operating with this capacity since 1976 and in recent years has been operating virtually in a steady-state storage-only mode, since spent fuel shipping operations have been curtailed. This facility currently operates under the requirements of $10 \mathrm{CFR} 72$, which contains licensing requirements for ISFSIs. Morris' operations, maintenance programs, personnel requirements, and costs are probably typical of those that would be encountered at future wet-storage ISFSIS.

To estimate costs for future utility-operated ISFSIs, the Morris Operation's personnel requirements were increased to reflect the likely staffing levels needed for utilities to comply with the regulations that will govern ISFSIs in the future (based on discussions with cognizant experts at commercial nuclear power plants).

\subsection{OPERATING COST CATEGORIES}

The following operating cost categories were compiled from several references:

Personnel:

Administration

Plant Operation

Plant Maintenance

Plant Services

Security

Custodial Services

Non-Personnel:

Operation and Maintenance -

Instrumentation and electrical maintenance

Mechanical maintenance 
Chemistry

Radioactive waste management system

\author{
Services - \\ Radiation protection and environmental monitoring \\ Utilities - \\ Electric power (only) \\ General and Administrative - \\ Licensing and inspection \\ Nuclear liability insurance
}

Costs associated with these categories were estimated for the prototype facility described later in this section (cost references are noted in Table 3.1).

Table 3.1 lists the costs that make up the total estimated annual cost of operating a spent fuel pool (or pools) as an ISFSI. Several electric utilities have estimated various costs associated with spent fuel storage. For example, Duke Power Company conducted an internal (proprietary) study estimating the costs of operating an ISFSI based on existing spent fuel storage pools costs at its nuclear power stations. ${ }^{(a)}$ Similarly, nuclear material handling facilities such as the Morris Operation, ${ }^{(b)}$ the West Valley Demonstration Project, ${ }^{(c)}$ and the retired Humbolt Bay nuclear power station have compiled spent fuel storage cost data based on years of operating experience. Table 3.1 was constructed from those sources, both published and unpublished reports, and interviews with cognizant experts listed in the reference section and in Appendix A.

\title{
3.3 COST ADJUSTMENTS FOR GEOGRAPHIC VARIATION
}

After costs for the model facility were estimated, adjustments were made to reflect more nearly a national average cost; for instance,

1. Duke Power's personnel costs ${ }^{(d)}$ were divided by 0.8 because the southeast region's personnel costs are about $80 \%$ of the U.S. average (Ball 1986; Claiborne et al. 1989).

(a) Memorandum from D. E. Oglesby to M. Robinson, July 21, 1989. "O\&M Cost Estimate for Support Required to Use Spent Fuel Storage Pool as an ISFSI." Duke Power Company, Charlotte, North Carolina.

(b) Personal communication with J. Kesman, Plant Operation and Maintenance Manager, Morris Operation, June 11, 1990. General Electric Corporation, Morris, Illinois.

(c) Personal communication with B. Conners, Fuel Program Manager, West Valley Nuclear Services Company, June 19, 1990. Westinghouse Electric Corporation, West Valley, New York.

(d) Internal communication, T. W. Wood to S. R. Rod, May 22, 1990. "Ops Cost After Shutdown." Pacific Northwest Laboratory, Richland, Washington. 
Table 3.1. Spent Fuel Pool Annual Costs for Long-Term Operation at a 750-MTU-Capacity ISFSI (Case 1 - No operating reactors onsite and one spent fuel pool. Table entries in 1989 dollars)

1. Personnel costs (items $1-35$ represent Morris Operation staffing levels)

\begin{tabular}{|c|c|c|}
\hline No. & Position Description & Annual Cost \\
\hline 1 & Facility Manager $^{(\mathrm{a})}$ & $\$ 70,000$ \\
\hline 2 & Plant Services Manager (Health Physics) ${ }^{(\theta)}$ & 52,000 \\
\hline 3 & Senior Services Technician $\# 1^{(b, c)}$ & 38,800 \\
\hline 4 & Senior Services Technician \# $2^{(b, c)}$ & 38,800 \\
\hline 5 & Senior Services Technician $\# 3^{(b, c)}$ & 38,800 \\
\hline 6 & Operation \& Maintenance Manager ${ }^{(\theta)}$ & 52,000 \\
\hline 7 & Maintenance Engineer $r^{(b, c)}$ & 44,600 \\
\hline 8 & Senior Maintenance Technician $\# 1^{(b, c)}$ & 36,000 \\
\hline 9 & Senior Maintenance Technician \#2 $2^{(b, c)}$ & 36,000 \\
\hline 10 & Senior Maintenance Technician $\# 3^{(b, c)}$ & 36,000 \\
\hline 11 & Maintenance Technician ${ }^{(b, c)}$ & 26,700 \\
\hline 12 & Operations Engineer ${ }^{(\mathrm{b}, \mathrm{c})}$ & 47,600 \\
\hline 13 & Lead Operations Technician $\# 1^{(b, c)}$ & 36,000 \\
\hline 14 & Lead Operations Technician $\# 2^{(b, c)}$ & 36,000 \\
\hline 15 & Lead Operations Technician $\# 3^{(b, c)}$ & 36,000 \\
\hline 16 & Lead Operations Technician $\# 4^{(b, c)}$ & 36,000 \\
\hline 17 & Operation \& Maintenance (O\&M) Technician $\# 1^{(b, c)}$ & 26,700 \\
\hline 18 & O\&M Technician \#2 $2^{(b, c)}$ & 26,700 \\
\hline 19 & O\&M Technician \# $3^{(b, c)}$ & 26,700 \\
\hline 20 & O\&M Technician \#4 ${ }^{(b, c)}$ & 26,700 \\
\hline 21 & O\&M Technician $\# 5^{(b, c)}$ & 26,700 \\
\hline 22 & O\&M Technician \# $6^{(b, c)}$ & 26,700 \\
\hline 23 & Safety/Security Engineer ${ }^{(b, c)}$ & 44,600 \\
\hline 24 & Secretary \#1 $(6, c)$ & 17,900 \\
\hline 25 & Personnel Administrator ${ }^{(b, c)}$ & 36,100 \\
\hline 26 & Buyer ${ }^{(a)}$ & 35,000 \\
\hline 27 & Security Guard \#1 $1^{(b, c)}$ & 22,800 \\
\hline 28 & Security Guard \#2 $2^{(b, c)}$ & 22,800 \\
\hline 29 & Security Guard \# $3^{(b, c)}$ & 22,800 \\
\hline 30 & Security Guard \#4 ${ }^{(b, c)}$ & 22,800 \\
\hline 31 & Security Guard \# $5^{(b, c)}$ & 22,800 \\
\hline 32 & Security Guard \# $6^{(b, c)}$ & 22,800 \\
\hline 33 & Security Guard \# $7^{(b, c)}$ & 22,800 \\
\hline 34 & Security Guard $\# 8^{(b, c)}$ & 22,800 \\
\hline 35 & Custodian $\# 1^{(a)}$ & 16,000 \\
\hline
\end{tabular}

(a) Based on comparable positions.

(b) Imternal communication, T. W. Wood to S. R. Pod, May 22, 1990. "Ops Cost After Shutdown." Pacific Northwest Laboratory, Richlend, Washington.

(c) Memorandum from D. E. Oglesby to M. Robinson, July 21, 1989. O\&M Cost Estimate for Support Required to Use Spent Fuel Storage Pool as an ISFSI." Duke Power Company, Charlotte, North Carolina. 
Table 3.1. (contd)

1. Personnel costs (items $36-46$ represented additional staffing for future ISFSI over Morris Levels)

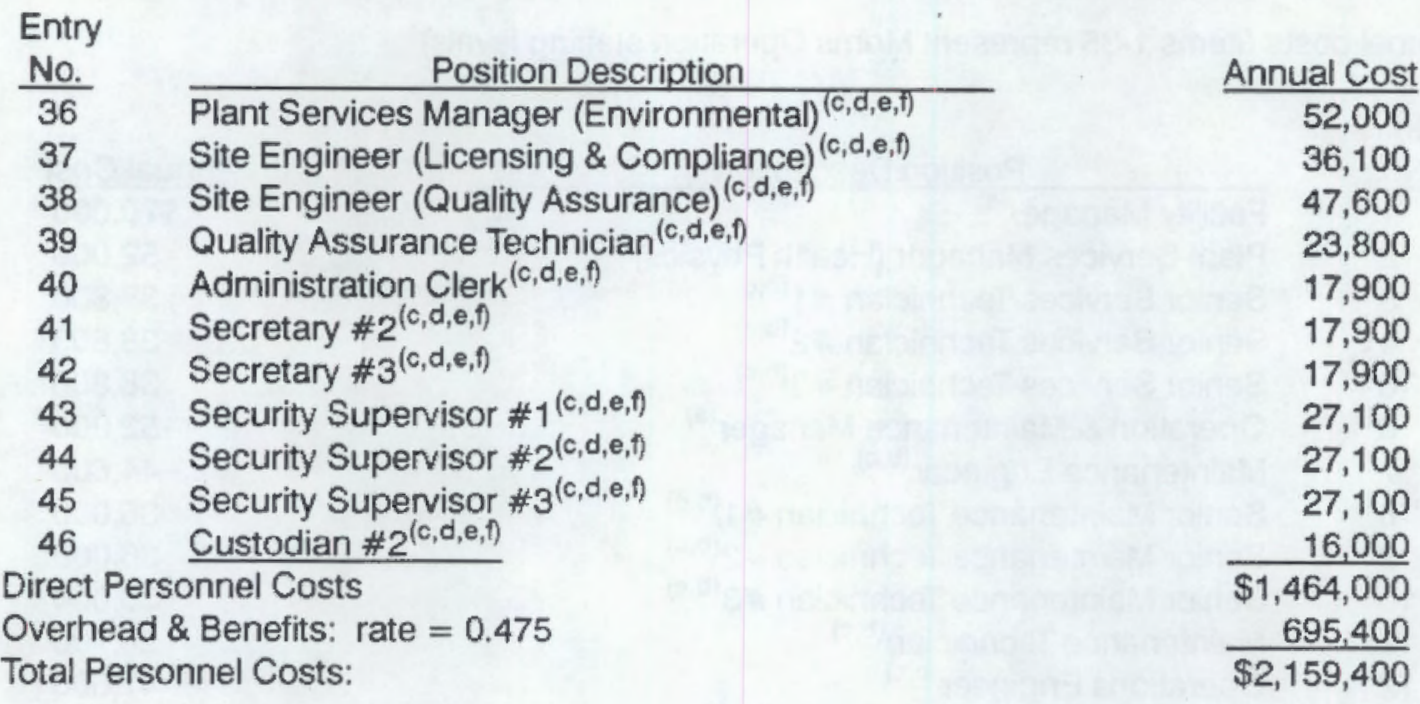

2. Operation \& Maintenance:

\section{Cost Category}

Instrumentation \& Electrical Maintenance (materiais \& supplies)

Annual Cost

Mechanical Maintenance (materials \& supplies)

$\$ 112,000$

130,000

251,000

Radwaste System

Onsite Processing (supplies)

53,000

Contract Removal \& Disposal

75,000

\section{Services:}

Radiation Protection/Environmental Monitoring (materials \& supplies)

25,000

4. Utilities:

Electric Power

160,000

$(2,000,000 \mathrm{kWh} / \mathrm{yr}$ * $\$ 0.08 / \mathrm{kWh})$

5. General \& Administrative (Wood et al. 1989):

Licensing \& Inspection

20,000

Nuclear Liability \& Property Insurance

400,000

Total Non-Personnel Costs:

$\$ 1,226,000$

Total Annual Operating Cost:

(c) Memorandum from D. E. Oglesby to M. Robinson, July 21, 1989. "O\&M Cost Estimate for Support Required to Use Spent Fuel Storage Pool as an ISFSI." Duke Power Company, Charlotte, North Carolina.

(d) Personal communication with B. Conners, Fuel Program Manager, West Valley Nuclear Services Company, June 19, 1990. Westinghouse Electric Corporation, West Valley, New York.

(e) Personal communication with J. Kesman, Plant Operation and Maintenance Manager, Morris Operation, June 11, 1990. General Electric Corporation, Morris, Illinois.

(f) Personal communications with R. I. Smith, June 1-21, 1990. Pacific Northwest Laboratory, Richland, Washington. 
2. Electric power costs from GE's Morris Operation were divided by 1.17 because Illinois' (specifically, the Chicago region's) electricity costs are approximately $117 \%$ of the national average (Census 1990).

Table 3.2 shows the results of these adjustments.

Although regional factors for material costs were available in Ball (1986), material cost adjustments were not made because the regional variations were far less than the uncertainty inherent in the material cost estimation method used in this study. In a Duke Power internal memorandum, ${ }^{\left({ }^{a}\right)}$ the costs of materials and supplies were estimated by multiplying the personnel cost in individual departments by 0.40 (since materials and supplies costs are assumed to be equal to $40 \%$ of personnel costs).

Table 3.2. Geographically Adjusted Annual Cost for a Generic 750-MTU-Capacity ISFSI Location (Case 1 - no operating reactors onsite and one spent fuel pool. Table entries in 1989 dollars)

Cost Category

Personnel Costs (Ball 1986; Claiborne 1989; Census 1990) ${ }^{(\mathrm{b}, \mathrm{c})}$

Total Materials and Supplies (Ball 1986; Claiborne 1989; Census 1990) ${ }^{\text {(d) }}$

Utilities (Electric Power) (Ball 1986; Claiborne 1989; Census 1990) ${ }^{(e)}$

General \& Administrative:

Licensing \& Inspection

Nuclear Liability \& Property Insurance ${ }^{(f)}$

Total Annual Operating Cost (initial estimate) for a 750-MTU-capacity pool at a Generic Location in the U.S.
Initial Annual Adjusted Cost Estimate ${ }^{(a)}$ Annual Cost

$\$ 2,159,400 \quad \$ 2,699,300$

$\$ 646,000 \quad \$ 646,000$

$\$ 160,000 \quad \$ 136,800$

\begin{tabular}{rr}
$\$ 20,000$ & $\$ 20,000$ \\
$\$ 400,000$ & $\$ 400,000$ \\
\hline
\end{tabular}

$\$ 3,385,400 \quad \$ 3,902,100$

(a) Based on Table 3.1.

(b) Memorandum from D. E. Oglesby to M. Robinson, July 21, 1989. 'O\&M Cost Estimate for Support Required to Use Spent Fuel Storage Pool as an ISFSI." Duke Power Company, Charlotte, North Carolina.

(c) Duke Power's estimated personnel costs were divided by 0.8 to account for the fact that the southeast region's personnel costs were approximately $80 \%$ of the U.S. average (in 1988),

(d) Personal communication with B. Conners, Fuel Program Manager, West Valley Nuclear Services Company, June 19, 1990. Westinghouse Electric Corporation, West Valley, New York.

(e) Morris Operation's electricity costs were divided by 1.17 to account for the fact that Illinois' electric utility costs were approximately $117 \%$ of the U.S. average (in 1988).

(f) Personal communications with J. P. Marone, Senior Vice President and General Counsel, American Nuclear Insurers, August 8 , 1990. Farmington, Connecticut.

\subsection{COST ADJUSTMENTS FOR POOL CAPACITY VARIATION}

Table 3.3 summarizes adjustments made to account for variations in spent fuel capacities among reactor sites.

(a) Memorandum from D. E. Oglesby to M. Robinson, July 21, 1989. "O\&M Cost Estimate for Support Required to Use Spent Fuel Storage Pool as an ISFSI." Duke Power Company, Charlotte, North Carolina. 
Table 3.3. Final Adjusted Annual Operating Cost of an Average Capacity (595-MTU-Capacity) ISFSI at a Generic U.S. Location (Case 1 - no operating reactors onsite and one spent fuel pool. Table entries in 1989 dollars)

Capacity Cost Factor: Adjustment for a Mean Capacity ISFSI:

Capacity of Morris Operation's Pool (750 MTU) ${ }^{(a)}$

Mean U.S. Commercial Spent Fuel Pool Capacity (595 MTU) ${ }^{(b)}$

Annual Cost vs. Capacity Formula; $\$ 1989=F(M T U)$ :

$\$ 2,363,000+\$ 1,286$ * (pool capacity in MTU) ${ }^{(c)}$

Annual Operating Cost of a 750-MTU pool (per formula)

$\$ 3,328,000$

Annual Operating Cost of a 595-MTU Pool (per formula)

$\$ 3,128,000$

Capacity Adjustment Factor $(\$ 3,128,000 \div \$ 3,328,000): 0.94$

Adjusted Annual Operating Cost of an Average-

Capacity (595 MTU) ISFSI at a Generic U.S. Location (0.94 X 3,902,100)

$\$ 3,670,000$

(a) Based on data from GE (1990).

(b) Based on data from DOE (1989).

(c) Based on data from McCartney and Cairns (1984) and expressed in 1989 dollars (see Subsection 3.4).

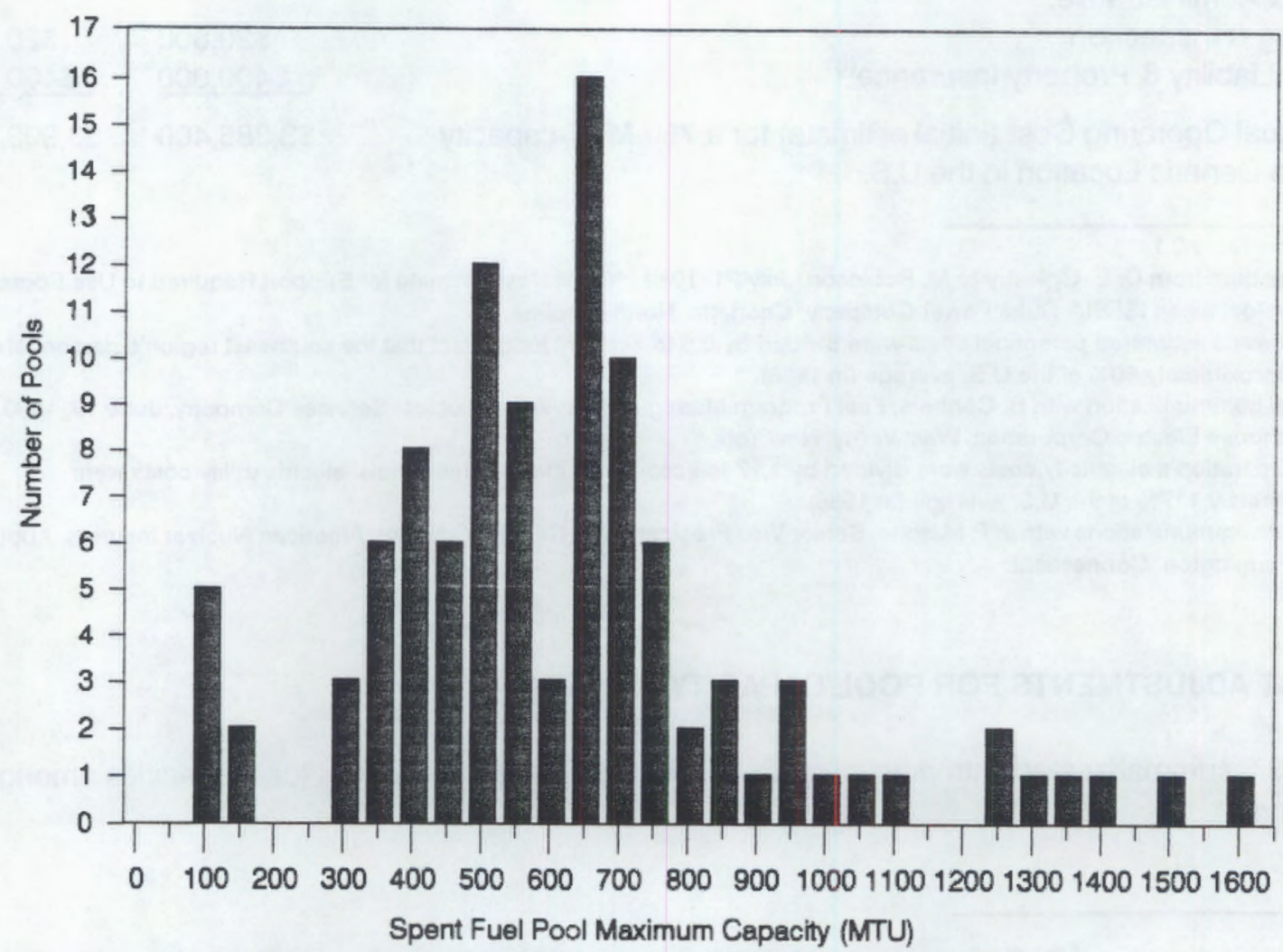

Figure 3.1. At-Reactor Spent Fuel Storage Capacities (Mean Capacity $=595$ MTU) 
There are presently 103 spent fuel pools in operation at 77 commercial nuclear power plants in the U.S., as shown in Figure 3.1 (DOE 1989). These pools have fuel storage capacities ranging from 81 MTU to 1,570 MTU, based on the nominal heavy metal content of spent PWR and BWR fuel assemblies (Hill et al. 1983; DOE 1989). An Electric Power Research Institute (EPRI) report on the cost of spent fuel storage shows a moderate correlation between pool operation cost and pool capacity (McCartney and Cairns 1984).

In Figure 3.2, the data from McCartney and Cairns (1984) are expressed in 1989 dollars, converted from the 1983 dollars used in the original report by applying "GNP deflator' factors from 1983 through 1988, as shown below (Census 1990):

\begin{tabular}{|c|c|}
\hline Year & GNP Deflator \\
\hline 1983 & 0.039 \\
\hline 1984 & 0.037 \\
\hline 1985 & 0.030 \\
\hline 1986 & 0.026 \\
\hline 1987 & 0.032 \\
\hline$\underline{1988}$ & 0.033 \\
\hline -1988 & 0.214 \\
\hline
\end{tabular}

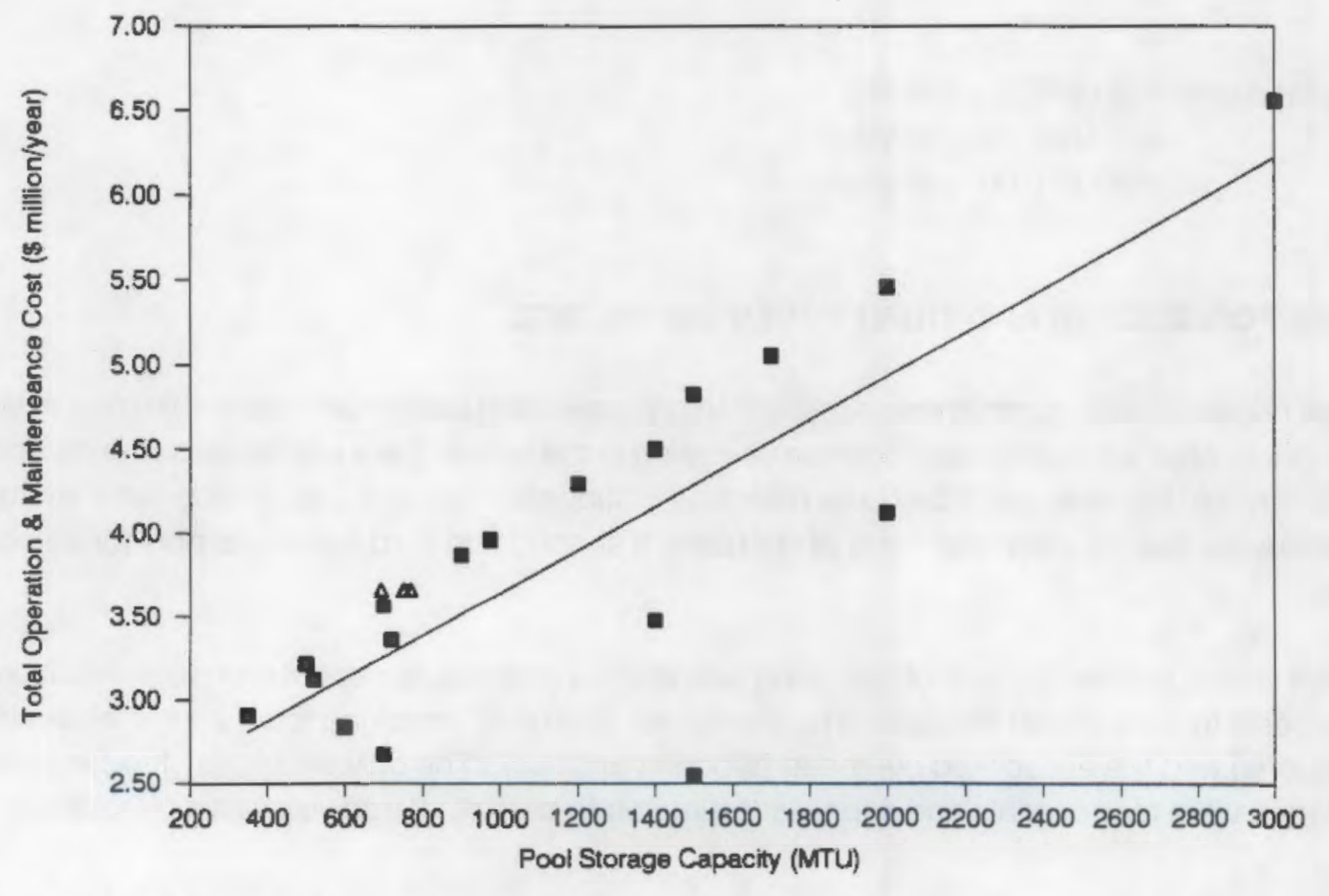

- Data (estimates from reference)

Regression Line

$\Delta \quad$ Morris Operation (estimate)

Figure 3.2. Spent Fuel Pool Operation Cost Estimates (McCartney and Cairns 1984) 
To adjust the cost estimate presented in Table 3.3 to reflect the mean capacity of U.S. spent fuel pools, 595 MTU, the cost of the 750-MTU prototype facility was modified as foliows:

A linear regression formula was derived from data in McCartney and Cairns (1984) (see Figure 3.2):

Cost (in 1989) dollars) $=f($ capacity $)$

$=\$ 2,363,000+\$ 1,286 \times$ capacity (in MTU)

Therefore: $\quad f(595 M T U)=\$ 3,128,000$ per year

$$
f(750 \mathrm{MTU})=\$ 3,328,000 \text { per year }
$$

From these two annual costs, a cost-scaling factor based on pool capacity was calculated:

$$
\text { Cost-scaling factor }=\frac{\$ 3,128,000}{\$ 3,328,000} \sim 0.940
$$

The geographically adjusted pool operation cost was multiplied by the capacity cost-scaling factor to yield the final adjusted annual operating cost for an average capacity spent fuel pool in a generic location in the U.S., shown at the end of Table 3.3:

$$
\begin{aligned}
\text { adjusted cost } & =\$ 3,900,000 \star 0.940 \\
& =\$ 3,666,000 \text { per year } \\
& \sim \$ 3,670,000 \text { per year }
\end{aligned}
$$

\subsection{COSTS FOR SECOND AND THIRD POOLS ON THE SITE}

At some nuclear power plants there is more than one operating reactor and more than one active spent fuel pool. Also, as more reactors cease operating in the future, there will be sites with no operating reactors, but more than one spent fuel pool operating in long-term storage (i.e., steady-state shutdown) mode. Tables 3.4 and 3.5 show the costs of operating a second and third spent fuel pool for these situations.

Table 3.4 shows the annual cost of operating one additional shutdown spent fuel pool. Additional personnel costs include a lead operations technician for each shift [requiring four full-time-equivalent (FTE) positions] and the associated overhead (Wood et al. 1989). The only additional non-personnel costs included were for materials and supplies (estimated to be $40 \%$ of additional personnel costs) ${ }^{\text {(a) (b) }}$

(a) Internal communication, T. W. Wood to S. R. Rod, May 22, 1990. "Ops Cost After Shutdown." Pacific Northwest Laboratory, Richland, Washington.

(b) Memorandum from D. E. Oglesby to M. Robinson, July 21, 1989. "O\&M Cost Estimate for Support Required to Use Spent Fuel Storage Pool as an ISFSI." Duke Power Company, Charlotte, North Carolina. 
Table 3.4. Annual Costs for Long-Term Operation of an Additional Spent Fuel Pool at an ISFSI (Case 2 - operating reactor(s) onsite, with one active spent fuel pool -orno operating reactors, with one inactive spent fuel pool already in operation; entries are in 1989 dollars)

Part 1) Prototype Facility

A) Additional Personnel Costs:

\begin{tabular}{|c|c|c|}
\hline Position Description & Annual Cost & Totajs \\
\hline Lead Operations Technician \#1 ${ }^{(a, b)}$ & $\$ 36,000$ & \\
\hline Lead Operations Technician \# $2^{(a, b)}$ & 36,000 & \\
\hline Lead Operations Technician \# $3^{(a, b)}$ & 36,000 & \\
\hline Lead Operations Technician \#4 $4^{(a, b)}$ & 36,000 & \\
\hline Subtota: & 144,000 & \\
\hline Overhead: rate $=0.475$ & 68,400 & \\
\hline Staft salaries + overhead subtotal: & $\$ 212,400$ & $\$ 212,400$ \\
\hline
\end{tabular}

B) Additional Non-Personnel Costs: ${ }^{(a, b, c)}$

Materials \& Supplies: $\quad 85,000$

Electric Power: ${ }^{(d)} \quad 160,000$

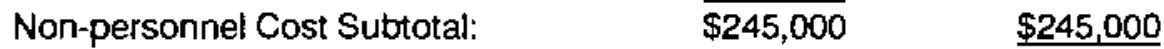

Total Annual Cost:

$\$ 457,400$

Part 2) Adjustments for Geographic and Capacity Variations

A) Geographic Variations

Cost Category

Personnel Costs:

Materials \& Supplies:

Electric Power:

Total Annual Cost:

B) Adjusted Cost of an Average Capacity (595 MTU) Pool at a Generic U.S. Location:

\author{
$\underline{\text { Initial Cost Estimate }}$
}

$\$ 212,400$

85,000

$\underline{160,000}$

$\$ 457,400$

(a) Internal communicetion, T. W. Wood to S. R. Rod, May 22, 1990. 'Ops Cost Atter Shutdown.' Pacific Northwest Laboratory, Richlend, Washinglon.

(b) Memorandum from D. E. Ogiesby to M. Robinson, July 21, 1989. 'O\&M Cost Estimete for Support Required to Use Spent Fuel Storage Pool as an ISFS!," Duke Power Company, Charlotte, North Carolina.

(c) Personal communications wish R. I. Smith, June 1-21, 1990. Pachic Northwest Laboratory, Richiand, Washinglon,

(d) Personal communication with J. Kesmen, Plant Operation and Maintenance Manager, Morris Operation, June 11, 1990. General Electric Corporation, Morris, Htinois. 
Table 3.5. Annual Costs for Long-Term Operation of a Second Additional Spent Fuel Pool at an ISFSI (Case 3 - operating reactor(s) onsite, with one active pool and one shutdown pool already in operation -or- no operating reactors, with two shutdown spent fuel pools already in operation; entries are in 1989 dollars)

Part 1) Prototype Facility

A) Additional Personnel Costs:

\begin{tabular}{|c|c|c|}
\hline Position Description & Annual Cost & Totals \\
\hline Lead Operations Technician \#1 & $\$ 36,000$ & \\
\hline Lead Operations Technician \#2 & 36,000 & \\
\hline Lead Operations Technician \#3 & 36,000 & \\
\hline Lead Operations Technician \#4 & 36,000 & \\
\hline Security Guard \#1 & 22,800 & \\
\hline Security Guard \#2 & 22,800 & \\
\hline Security Guard \#3 & 22,800 & \\
\hline Security Guard \#4 & 22,800 & \\
\hline Subtotal: & $\overline{\$ 235,200}$ & \\
\hline Overhead: rate $=0.475$ & 111,700 & \\
\hline Staff salaries + overhead subtotal: & $\$ 346,900$ & $\$ 346,900$ \\
\hline
\end{tabular}

B) Additional Non-personnel Costs:

\begin{tabular}{|c|c|c|}
\hline $\begin{array}{l}\text { Materials \& Supplies: } \\
\text { Electric Power: } \\
\text { Non-Dersonnel Cost Subtotal. }\end{array}$ & $\begin{array}{l}\$ 138,800^{(a)} \\
\frac{160,000}{\$ 298,800}\end{array}$ & 88.800 \\
\hline tal Annual Cost: & & $\frac{\$ 250,000}{\$ 645,700}$ \\
\hline
\end{tabular}

Part 2) Adjustments for Geographic and Capacity Variations

A) Geographic Variations

Cost Category

Personnel Costs:

Materials \& Supplies:

Electric Power:

Total Annual Cost of 750-MTU-

capacity storage pool

B) Adjusted Cost of an Average Capacity (595 MTU) Pool at a Generic U.S. Location:

\section{Initial Cost Estimate}

$\$ 346,900$

138,800

160,000

$\$ 645,700$

$\$ 645,700$ 
and additional electric power costs. The same geographic and capacity adjustments were made to the total cost in Table 3.4 as were made in Tables 3.2 and 3.3.

Table 3.5 shows the annual cost of operating a second additional inactive spent fuel pool. Additional personnel costs include a lead operations technician and an additional security guard for each shift (requiring four FTE lead operations technician positions and four FTE security guard positions) and the associated overhead (Wood et al. 1989). The only additional non-personnel costs included were for materials and supplies (estimated to be $40 \%$ of additional personnel costs) and additional electric power costs. ${ }^{\text {(a) (b) }}$ The same geographic and capacity adjustments to the total cost were made in Table 3.5 as were made in Tables 3.2 and 3.3.

\subsection{ADDITIONAL ASSUMPTIONS}

The overhead rate for personnel is assumed to be $47.5 \%$, which is midway between the extremes of the range of overhead rates reported by utilities $(40$ to $55 \%){ }^{\text {(b) (b) }}$ The overhead rates reported by utilities seem low compared with other typical industrial overhead rates; however, the utility-reported rates were used in these estimates. Nuclear liability and property insurance was initially estimated to cost about $\$ 400,000$ per year per ISFSI (Wood et al. 1989). Cost figures are based on December 31,1989 , dollars.

Discussions with representatives of American Nuclear Insurers (ANI) revealed that typical annual cost to a nuclear utility site with an operating reactor is about $\$ 800,000$ for nuclear liability insurance and $\$ 2,000,000$ for property insurance, totaling $\$ 2,800,000$ per year. The best ANI estimate for the cost of similar coverage for a nonoperational site with spent fuel present (i.e., an ISFSI) would be from 10 to $25 \%$ of the total nuclear insurance cost for an operating reactor site, or from about $\$ 280,000$ to about $\$ 700,000$ per year. This range of insurance costs is still speculative, however, since ANI has not yet insured such a facility. ${ }^{\text {(c) }}$ Given the uncertainty, the initial estimated annual insurance cost of $\$ 400,000$ was retained for use in this study.

Only costs associated with long-term spent fuel storage (i.e., steady-state operation) are included. Costs associated with receiving and shipping spent fuel elements are excluded (e.g., additional manpower, equipment, etc., for either receiving/unloading or loading/shipping transport casks).

(a) Internal communication, T. W. Wood to S. R. Rod, May 22, 1990. "Ops Cost After Shutdown." Paciitic Northwest Laboratory, Richland, Washington.

(b) Personal communications with R. I. Smith, June 1-21, 1990. Pacific Northwest Laboratory, Richland, Washington.

(c) Personal communications with J. P. Marone, Senior Vice President and General Counsel, August 8, 1990. American Nuclear Insurers, Farmington, Connecticut. 
Other costs not included in this analysis are

- Facility decommissioning costs, including the cost of final disposition of liquid and solid radioactive wastes currently accumulated on the site, for eventual disposal at decommissioning.

- Local, county, and state fees and taxes; notably, property taxes.

- Additional costs related to insurance, licensing, inspection, and regulatory compliance for additiona! pools. 


\subsection{REFERENCES}

10 CFR 72. 1990. U.S. Nuclear Regulatory Commission. Licensing Requirements for the Independent Storage of Spent Nuclear Fuel and High-Level Radioactive Waste. U.S. Code of Federal Regulations.

Ball, J. R. 1986. A Handbook for Quick Cost Estimates: A Method for Developing Quick Approximate Estimates of Costs for Generic Actions for Nuclear Power Plants. NUREG/CR-4568, ANL/EES-TM-297. Argonne National Laboratory, Argonne, Illinois.

Bureau of the Census. 1990. Statistical Abstract of the United States: 1990. 110 $10^{\text {th }}$ Edition, U. S. Department of Commerce, Washington, D.C.

Claiborne, E., F. Sciacca, G. Simion, and G. Baca. 1989. Generic Cost Estimates: Abstracts from Generic Studies for Use in Preparing Regulatory Impact Analyses. NUREG/CR-4627 Rev. 1, Science \& Engineering Associates, Albuquerque, New Mexico.

General Electric Corporation (GE). 1990. Consolidated Satety Analysis Report for Moms Operation. March 1990 Update. NEDO-21326D4, USNRC Docket \#70-1308, General Electric Corporation, Pittsburgh, Pennsylvania.

Hill, O. F., A. M. Platt, and J. V. Robinson. 1983. Nuclear Fact Book. PNL-4239 Edition 2, Pacific Northwest Laboratory, Fichland, Washington.

Humphreys, K K, L L Clark, M. R. Shay, S. M. Short, and D. L Stiles. 1991. System Engineering Cost Analysis Capability Technical Reference Manual. PNL-7443, Vol.1, Pacific Northwest Laboratory, Richland, Washington.

McCartney, J. S., and R. B. Cairns. 1984. Cost Comparisons for On-Site Spent Fuel Storage Options. EPRI NP-3380, Electric Power Research Institute, Palo Alto, Califomia.

U.S. Department of Energy (DOE). 1989. Spent Fuel Storage Requirements 1989-2020. DOE/RL-89-30, Richland Operations Office, Richland, Washington.

Wood, T. W., S. M. Shon, M. G. Woodruff, M. K. Altenhofen, and C. A. MacKay. 1989. MRS Systems Study Task G Report: The Role and Functions of Surtace Storage of Radioactive Material in the Federal Waste Management System. PNL-6876, Pacific Northwest Laboratory, Richland, Washington. 

APPENDIX A

BACKGROUND SURVEY CONTACTS 


\section{APPENDIX A}

\section{BACKGROUND SURVEY CONTACTS}

American Nuclear Insurers:

Bahtimore Gas \& Electric:

Battelle Memorial Institute:

Pacific Northwest Laboratory:

Duke Power Company:

Electric Power Research Institute:

General Electric Corporation, Morris Operation:

Pacific Gas \& Electric Company, Humbolt Bay Power Station:

U.S. Nuclear Regulatory Commission:

Virginia Power Company:
Joseph P. Marrone, Sr. VP \& General Counsel Richard Jones

Robert H. Beal!

V. Pasupathi

Joseph W. Ray

James $M$. Creer

Kenneth K. Humphreys

Richard I. Smith

Steven M. Short

Thomas W. Wood

Robert Rasmussen

Ray Lambert

T. E. Ingels, Plant Manager James Kesman, O\&M Manager

George Sarkisian

Pichard Bangart

Lewis Bykoski

Peter Ericson

Timothy Johnson

Timothy Margolis

Daniel Martin

John Roberts

John Surmeier

Lena Thomas

Robert Wood

Marvin Smith 
Westinghouse Electric Corporation,

West Valley Nuclear Services Company:

Fuel Program:

Cost Accounting:

Bernard Conners, Manager

Todd Cotter

Bruce Wiesen 
APPENDIX B

MORRIS OPERATION ORGANIZATION CHART 


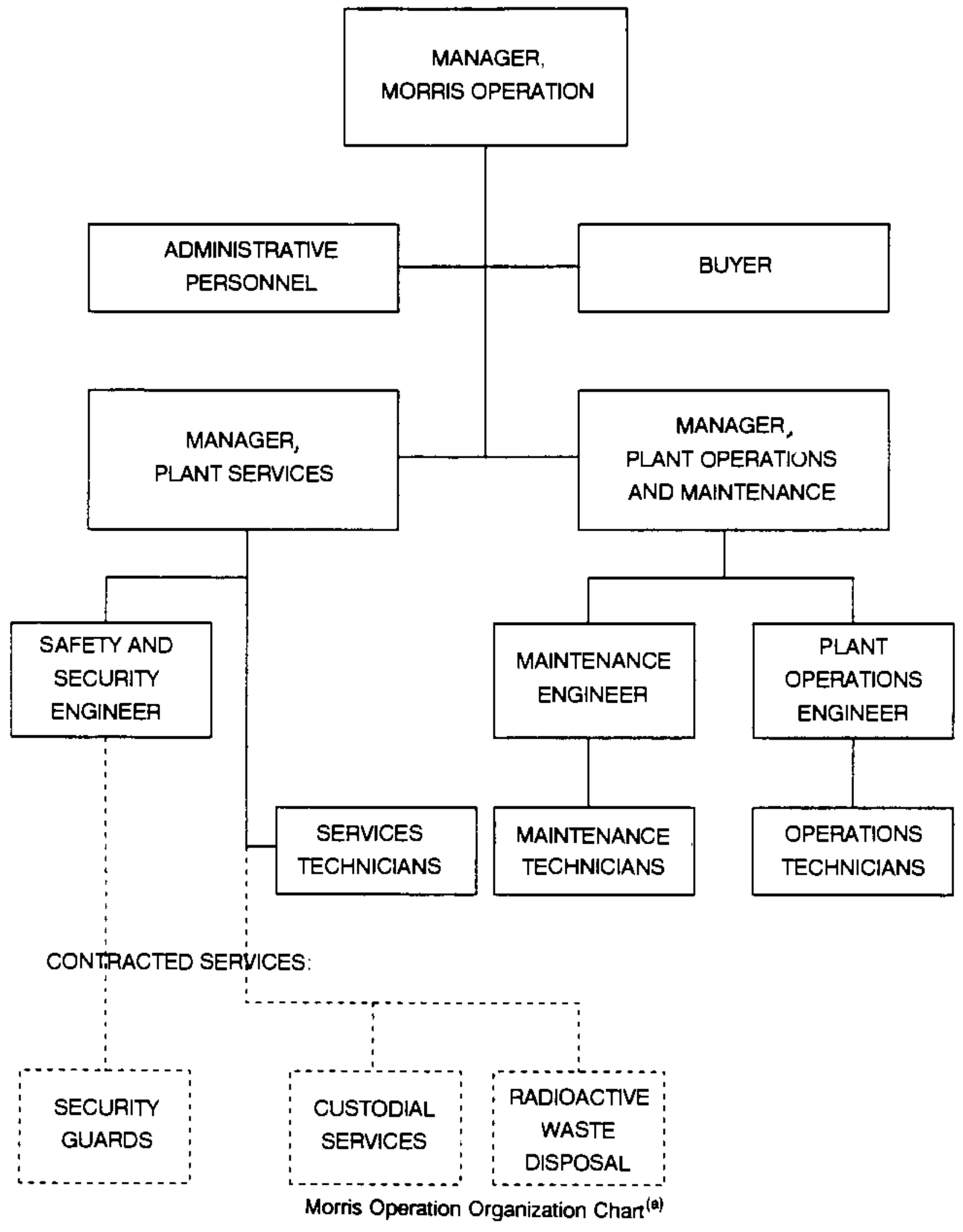

(a) 'Ops Case alter Shutdown.' Imernal communication from T. W. Wood to S. R. Rod, May 22 , 1990. Pacific Northwest Laboratory, Richland, Washington. 


\section{DISTRIBUTION}

No. of

Copies

OFFSITE

12 DOE/Office of Scientific and Technical Information

14 Office of Civilian Radioactive Waste Management U.S. Department of Energy tooo Independence Ave., SW Washington, DC 20545

ATTN: J. Carlson, RW-40

R. Blaney, RW-4

A. Brownstein, RW-40

W. Danker, RW-4

S. Gomberg, RW-322

H. Hale, RW-30

T. Isaacs, RW-43

C. Kouts, RW-40

W. Lemeshewsky, RW-30

R. Milner, AW-40

T. Pollog, RW-40

J. Saltzman, RW-5

D. Shelor, AW-30

J. Williams, RW-40

3 Yucca Mountain Project Office

U.S. Department of Energy

P.O. Box 98518

Las Vegas, NV 89183-8518

ATTN: $M$. Cloninger

C. Gertz

G. Rodriguez

17 Battelle Washington Operations 370 L'Enfant Promenade

Suite 900

Washington, DC 20024-2115

ATTN: C. Mackay

J. Strah!

S. Rod (15)
No. of

Copies

2 Sandia National Laboratory

Division 6311

Albuquerque, NM 87105

ATTN: A. Dennis

G. Hertel

4 Roy F. Weston, inc.

955 L'Enfant Plaza, SW

Washington, DC 20024

ATTN: N. Dayem

J. DiNunno

M. Conroy

J. Lilly

3 E. R. Johnson \& Associates, Inc. 10461 White Granite Dr.

Suite 204

Oakton, VA 22124

ATTN: B. Cole

E. Johnson

N. McLeod

2 Lawrence Livermore National Laboratory

P.O. Box 806

Livermore, CA 94550

ATTN: L. Ballou

M. Revelli

JK Associates

1001 Spring Street

Suite 406

Silver Spring, MD 20910

ATTN: T. Cotton 
No. of

Copies

2 Oak Ridge National Laboratory P.O. Box X

Oak Ridge, TN $\mathbf{3 7 8 3 0}$

ATTN: D. Joy

W. McClain

2 DOE Field Otfice, Richland

D. C. Langstaft

J. J. Sutey
No. of

Copies

15 Pacific Northwest Laboraton

S. Q. Bennett

G. J. Konzek

M. R. Kreiter

R. W. McKee

M. R. Shay

S. R. Short

R. I. Smith

T. W. Wood

M. G. Woodrutt

Publishing Coordination

Technical Report Files (5) 